\title{
Balancing competing policy demands: the case of sustainable public sector food procurement
}

Journal of Cleaner Production (2015) In Press

http://dx.doi.org/10.1016/i.jclepro.2015.07.065

Julie Smith a. (* corresponding author)

a Centre for Food Policy. Department of Sociology, School of Arts and Social Sciences, City University London, Northampton Square, London EC1V 0HB. UK

email: julie.smith.1@city.ac.uk

Gunilla Andersson b.

b. Project Manager Strategic Sustainability, Malmö Stad, Miljöförvaltningen,

[Environment Department], Avdelningen för Konsumtion och livsstil / Lifestyle and Consumer Affairs

Bergsgatan 17 SE-205 80 Malmö. Sweden

email: gunilla.i.andersson@malmo.se

Robin Gourlay c.

c. Food and Drink Policy, The Scottish Government, Saughton House, EDINBURGH

EH113XD

email: robin.gourlay@scotland.gsi.gov.uk

Sandra Karner d.

d. Inter-University Research Centre on Technology, Work and Culture (IFZ), Alpen-Adria Universität Klagenfurt I Vienna I Graz, Schlögelgasse 2, 8010 Graz, Austria

email: sandra.karner@aau.at

Bent Egberg Mikkelsen e.

e. Department of Clinical Medicine, Copenhagen, Aalborg University, Frederikskaj 10

Building: B, Room: B2 2450 København SV, DK

email: bemi@plan.aau.dk

Roberta Sonnino ${ }^{\mathrm{f}}$

f. School of Planning and Geography, Cardiff University, Glamorgan Building

King Edward VII Avenue, Cardiff CF10 3WA. Wales, UK

email: sonninor@cardiff.ac.uk

David Barling g.

g. Centre for Agriculture, Food \& Environmental Management,

Department of Biological \& Environmental Sciences, University of Hertfordshire,

College Lane, Hatfield, Hertfordshire AL10 9AB, UK.

email: d.barling@herts.ac.uk 


\title{
Balancing competing policy demands: the case of sustainable public sector food procurement.
}

\begin{abstract}
A focus on market-based green growth strategies to pursue sustainability goals neglects the pursuit of understanding how human health is interwoven with the health of ecosystems to deliver sustainability goals. The article argues that clarifying the difference between green and sustainable public sector food procurement, with political continuity that supports and enables policymakers and practitioners to take an incremental approach to change, makes an important contribution to delivering more sustainable food systems and better public health nutrition. Five European case studies demonstrate the reality of devising and implementing innovative approaches to sustainable public sector food procurement and the effects of cultural and political framings. How legislation is enacted at the national level and interpreted at the local level is a key driver for sustainable procurement. Transition is dependent on political will and leadership and an infrastructure that can balance the economic, environmental and social drivers to effect change. The development of systems and indicators to measure change, reforms to EU directives on procurement, and the relationship between green growth strategies and sustainable diets are also discussed. The findings show the need to explore how consistent definitions for green public procurement and sustainable public procurement can be refined and standardized in order to support governments at all levels in reviewing and analysing their current food procurement strategies and practices to improve sustainability.
\end{abstract}

Key words: Sustainable public procurement; green growth strategies; public health nutrition; sustainable diets; EU procurement regulation; urban and regional governments.

\section{Introduction}

Recognising that food purchasing and catering services, including those in hospitals, care homes, schools, prisons and state companies etc., represent a significant part of public sector procurement budgets, the central premise of this article is that there is a need for clarity about what is meant by 'green' public sector food procurement and 'sustainable' public sector food procurement. The dominant economic paradigm has led to a growing focus on market-based green growth strategies to pursue sustainability goals and, it is argued, an ecological shift is required in order to further understanding of how human health is interwoven with the health of eco-systems, and to enable policymakers and practitioners to move towards creating more sustainable food systems and better public health nutrition.

Public sector procurement, representing all of the goods and services purchased with public money, represents 13 to 20 per cent of gross domestic product (GDP) in OECD countries, including 17 percent of the EU's GDP (Evans et al, 2010), while in developing countries estimates are much higher and range from 30 to 70 percent of GDP (Perera, 2012). Procurement has been promoted as one means of reaching environmental goals 
since the 2002 World Summit on Sustainable Development and the Marrakech Task Force (2006-11) developed an approach for implementing sustainable public procurement (SPP) in both developed and developing countries. Since Rio +20 (2012), there has been a renewed focus on SPP as part of green growth strategies. These debates suggest that by purchasing environmentally and socially preferable goods, governments can make significant impacts on green economy transformation as part of sustainable development goals (OECD, 2014; GGBP, 2013). However, some argue that transformation to a green economy - defined as one that results in 'improved human well-being and social equity, while significantly reducing environmental risks and ecological scarcities' (UNEP, 2012) - could pose major challenges for governance mechanisms if it is to move the economy in a direction that benefits society as a whole and particularly the poor and vulnerable (Benson, 2014). Others (Garnett, 2014) point out that definitions of sustainability vary, stakeholders can have different priorities within the three 'pillars' of sustainable development and distinctions between 'green' and 'sustainable' can be amorphous.

The article draws on case study research conducted as part of the Foodlinks ${ }^{1}$ project that aimed to 'revalue' public sector food procurement. It analyses five European case studies where innovative public procurement policies and practices have been successfully implemented and provides an overview of what change is happening across Europe. More explicitly, it analyses how complex relationships and synergies between economic, environmental and social concerns, as determinants of SPP, were balanced, and how the dynamic between policy and practice supported change. The five case studies can be seen as microcosms of change for wider systems of implementation, and the article more broadly examines the relationship between green growth strategies and the emerging discourse on sustainable diets that takes the debate beyond 'green' initiatives to the social and equity impacts of healthy food systems and better public health nutrition.

The article begins by reviewing current definitions of 'green' and 'sustainable' public procurement and discusses how environmental, economic and social impacts are interpreted, 'measured' and integrated within current public sector food procurement practice. It then briefly charts the multi-level policy response. The methods section is followed by the case study findings and the discussion looks beyond 'green' to include recent change in procurement regulations. Wider systems of implementation are considered and the relationship between green growth strategies and the emerging

${ }^{1}$ http://www.foodlinkscommunity.net/1132.html (accessed 18 August 2014) 
discourse on sustainable diets is explored. Key areas for future research are identified, and concluding remarks are made about future trajectories of green growth strategies and sustainable diets, and on the significance of the findings for more sustainable public sector food procurement at all levels of government.

\subsection{Green and sustainable public procurement}

Although there are numerous definitions for green and sustainable procurement, the examples used in Table 1 that provides examples of how green and sustainable public procurement are defined and distinguished, typifies a lack of clarity between the two concepts. Green public procurement (GPP) definitions focus on environmental impacts whilst those used for SPP are at best 'fuzzy' and at worst, confusing. The EU website example illustrates this by including explanatory text on 'Practical differences' between GPP and SPP. This suggests that most EU public authorities prioritise GPP but see this as situated within the broader context of SPP.

Table 1: Examples of how green and sustainable public procurement are defined and distinguished in the literature.

\begin{tabular}{|c|c|}
\hline $\begin{array}{l}\text { Evans et } \\
\text { al, } 2010\end{array}$ & $\begin{array}{l}\text { - GPP focuses only on environmental areas of concern; } \\
\text { - SPP potentially encompasses a range of areas, but largely focuses on social and } \\
\text { environmental aspects. }\end{array}$ \\
\hline $\begin{array}{l}\text { EC } \\
\text { website }^{2}\end{array}$ & $\begin{array}{l}\text { - GPP means that public authorities seek to procure goods, services and works } \\
\text { with a reduced environmental impact throughout their life-cycle compared to } \\
\text { goods, services and works with the same primary function that would otherwise } \\
\text { be procured; } \\
\text { SPP means that public authorities seek to achieve the appropriate balance } \\
\text { between the three pillars of sustainable development - economic, social and } \\
\text { environmental - when procuring goods, services or works at all stages of the } \\
\text { project. } \\
\text { Practical differences } \\
\text { Many public authorities in the EU are implementing GPP as part of a broader } \\
\text { approach to sustainability in their purchasing which also addresses the economic } \\
\text { and social aspects. }\end{array}$ \\
\hline
\end{tabular}

Moreover, as Ahi and Seurcy (2013) note, the terms 'green' and 'sustainable' are often used interchangeably. This could present an illusion of progress towards more sustainable procurement practices or even an implicit assumption that green procurement will inevitably result in a shift towards more sustainable procurement. It is argued that failing to address these inconsistencies could lead to future confusion in the development of theory and practice (Bratt et al, 2013; Preuss 2007). In addition, Akenji (2013) suggests that GPP by governments and public institutions is more akin to green consumerism (GC) - namely, the production, promotion and preferential consumption of

${ }^{2}$ http://ec.europa.eu/environment/gpp/versus en.htm accessed 8 September 2014 
goods and services on the basis of their pro-environment claims (such as eco-labelling schemes, eco-efficient production standards etc.) rather than the promotion of sustainable consumption (SC) where change in consumption behaviour needs to be accompanied by change in infrastructures (social and physical).

\subsection{Environmental priorities}

One explanation for why there has been less integration and implementation of social and economic impacts in public procurement tenders and contracts is that the development of methods and techniques to measure environmental impacts is more advanced and they are quantifiable. In a recent review of GPP/SPP in nine EU member states plus Norway, Evans et al (2010) found that all case study countries cite the use of environmental life cycle assessment (LCA) (where available) as part of their public procurement strategies but social criteria were not that well established. In his review article on green consumerism, Akenji (2013:13) also suggests that the economic growth dogma that dominates government and market promoted GC is 'carefully calibrated to not slow down the economy but to operate as a peripheral activity that safeguards only against the most damaging and immediate environmental problems.'

\subsection{Economic power and shifting priorities}

Others take this further and posit that European public sector food procurement contracts tend to be awarded on the basis of 'best value' and 'the economically most advantageous tender' (i.e. low cost), with little or no consideration for the effects on human health and the environment of the entire agrifood cycle' (Morgan and Sonnino, 2008). Some recent research (OECD, 2012) suggests that not only is there a lack of professionalization in procurement (with it being regarded as an administrative rather than strategic objective), but also that risks and opportunity costs are rarely assessed when using it as a policy lever to support socio-economic and environmental objectives. However counteracting this, a growing body of literature on cities as environmental leaders is emerging (Puppim de Oliveira et al, 2013) alongside research that identifies local governments as key players for 'greening' public procurement (Nogueiro and Ramos, 2014). Although Perera (2012) notes that proliferation of standards, claims and labels in the green product marketplace has exacerbated confusion amongst procurement officers.

\subsection{Integrating social and health priorities}


Another body of work examines how the role of small businesses (SMEs) as suppliers to public authorities has not only environmental benefits through provision of green products or technology, in particular for the procurement of organic food, but also for local economic development, especially in low-income areas (Walker and Preuss, 2008). Others explore the benefits to local economies of green purchasing that focuses on social and economic benefits associated with more sustainable and better quality food procurement and its benefits for public health (Morgan 2015; Sonnino, 2009). This knowledge that governance systems can empower local actors, including small-scale producers and suppliers, has reinforced recognition that dietary change at the population level requires more than 'green' options, including the need to manage supply chains sustainably (Lang and Barling, 2013). There is an emerging food policy discourse on the relationship between nutrition and sustainability. Recent debates (Lang, 2014; Macdiarmid, 2013) have focussed on the concept of a 'sustainable diet' that 'promotes environmental and economic stability through low-impact and affordable, accessible foods, while supporting public health through adequate nutrition' (Johnston et al, 2014:420). To date, most of this work is driven by the environmental agenda, and the challenge is how to make food production more environmentally sustainable and resilient while paying greater attention to nutritional quality (Garnett, 2014). Key components of a sustainable diet include eating less meat and only sustainable or certified fish. It also includes storing vegetables (where possible) and eating perishable produce in season. Eating less sugar and minimizing food waste are other key components (ibid.).

These multiple dimensions for creating more sustainable public sector food procurement raise enormous challenges for policymakers and practitioners and, following Puppim de Oliveira et al, 2013 who suggest that sustainability begins with political ambition, the next section charts the policy response.

\subsection{The policy response}

At the global level, the recent emphasis on green growth strategies has resulted in newly negotiated text for the international WTO Global Procurement Agreement (GPA, April $2012^{3}$ ) that includes environmental characteristics as indicative evaluation criteria for government procurement. However, as de Schutter (2014) points out, there is no binding international definition on what constitutes a SPP scheme. There has also been a parallel

3

https://www.ustr.gov/sites/default/files/GPA\%20113\%20Decision\%20on\%20the\%20outcomes\%20of\% 20the \%20negotiations\%20under\%20Article\%20XXIV\%207.pdf Accessed 24 November 2014 
policymaking response at the EU level where GPP has re-emerged as a key objective of the new Europe 2020 strategy to help support the shift towards a resource efficient and low-carbon economy. In February 2014, new directives for the reform of public procurement were adopted to support these policy objectives and harmonize GPP within Europe. ${ }^{4}$ These aim to address a perceived lack of clarity about how to take social and environmental criteria into account in the old directives (2004/17 and 18) and ensure greater inclusion of common societal goals in the procurement process, including environmental protection, social responsibility and public health. The new provisions include simplified rules and procedures, the right to value social considerations when evaluating tenders, the use of labelling, and life cycle costing.

The EU reforms could improve access to markets for small food producers and SMEs through more opportunities for public sector food procurement contracts. Firstly, simplified rules and procedures should enable public authorities to use more contract 'lotting' - where large contracts for food commodities are divided into more manageable lots that make tendering a possibility for SMEs. Secondly, by widening the range of criteria (including environmental, social and labour requirements) through life cycle costing that defines the object of procurement, the reforms could expand how public authorities make decisions for awarding contracts when assessing which tender is the most 'economically advantageous' (see also Morgan and Sonnino, 2008 and the case of East Ayrshire (below)). Finally, commitments made at the national level, as a primary determinant of the extent to which SPP is implemented (Brammer and Walker, 2011), could increase more sustainable food procurement at the local level. For example in Scotland, SPP is at the heart of the Procurement Reform Act (2014) and enshrines the duty of sustainable procurement within its legislative framework, and new Guidelines for NHS catering (currently out for consultation) could make Scottish hospitals legally obliged to serve more nutritious meals to patients.

As has already been noted, there has been more practical implementation of SPP at regional and city levels. This has been driven by local politicians and by recent policy developments associated with initiatives that aim to promote healthy and sustainable food to the public through more sustainable public procurement initiatives. These include local governments promoting strategies to 'green' their local economies and adopting environmental purchasing plans, practices and tools (Nogueiro and Ramos, 2014; Testa

${ }^{4}$ Directive 2014/24/EU replacing directive 2004/18/EC; Directive 2014/25/EU replacing directive 2004/17/EC and new Directive 2014/23/EU 
et al, 2014) and that also make links to regional development and entrepreneurship (Preuss, 2011).

\section{Methods}

Set within this contextual background, the Foodlinks research programme (2011-2013) experimented with knowledge brokerage activities (KBAs) to promote more sustainable food systems using the concept of communities of practice (CoPs). European scientists, policy officials, practitioners and civil society organisations participated with others interested in urban food strategies, short food supply chains and/or public sector food procurement in three CoPs. The research covered in this article focuses on the activities of the public sector food procurement $\mathrm{CoP}$ - with an 'internal' membership of 12 project partners from six European countries and nine organizations (scientists (8) and policy officials (4)) and 'external' others from outside the project, including civil society organisations.

\subsection{The notion of the Community of Practice in Foodlinks}

Lave and Wenger's (1991:98) seminal work on CoPs acknowledges that although those involved have different view-points, coherence comes from "participation in an activity system about which participants share understandings concerning what they are doing and what that means for their lives and for their communities." Although the CoP was established and built up in a pragmatic, slightly artificial way (being a process of project activity, rather than emerging naturally around a topic between those with a shared interest in its purpose), the CoP acted as an arena for exchange and investigation of public procurement dynamics, logistics and standards around sustainable food and learning. Knowledge brokerage activities brought scientists (academic researchers) and policy officials together with others to build learning communities using a range of embodied and virtual knowledge brokerage tools. These created both face-to-face interaction and online virtual arenas that enabled members to experiment with and develop new ways of sharing and brokering knowledge that were relevant for their work 'on the ground' (for full details of the CoP process and activities, not included within the focus of this article, see Smith and Barling, 2013).

Wenger et al. (2002) highlight three defining features of a CoP: (i) the domain (theme) the reason for people to come together; (ii) the practice - the framework, ideas, tools, styles that people share; and (iii) the community - the importance of continued 
interaction, to build relationships and trust for effective collaboration and thus, for the performance of the CoP. As the Public Procurement CoP became established, it became clear that cultural approaches and political solutions to sustainable food and its public procurement differed throughout Europe and this raised questions about its performance. There was agreement that the CoP required a unifying aim (a framework for collaboration) to exchange knowledge and practical experience and, importantly, to build relationships, trust and continuity of interaction between the different stakeholder groups that came from municipal administrations, urban, regional and national governments, European platforms, civil society and the wider academic community. This recognition resulted in the decision to use KBAs to collaborate on a report, Revaluing Public Sector Food Procurement in Europe: an action plan for sustainability 5 (Barling et al, 2013). This report was built around case studies of innovative public sector food procurement practice that were drawn from CoP members' own experience and that also included a two-step Action Plan to encourage urban governments and municipal administrations to take up the challenge of more sustainable purchasing practices.

\subsection{Data collection and analysis}

Data collection for the report began with CoP members' proposals for case studies via a 'wiki' ${ }^{6}$ on a web-based platform (seven were suggested); five case studies offered possibilities for in-depth analysis and were selected. The report was written as a joint collaboration over 15 months using the 'wiki' as an on-line tool; this involved CoP members who had proposed the case studies posting information under a set of prescribed headings: i.) what change was happening; ii.) the driving forces that made change possible; iii.) what aspects of sustainability had been prioritized and why; and iv.) the main challenges encountered. Other CoP members responded to the postings, posed questions and made suggestions for the case study 'initiators' to respond to on the 'wiki'; this built the case study data in a dynamic way and provided a successful means of virtual engagement and interaction between members around a shared knowledge-based activity. In the final stages of publication, editorial oversight was provided by the project co-ordinators.

http://www.foodlinkscommunity.net/fileadmin/documents_organicresearch/foodlinks/publications/Food links report low.pdf (accessed 21 August 2014).

${ }^{6}$ Wiki software is a type of collaborative software that runs a wiki system, allowing web pages to be created and edited using a common web browser. 
The process of semi-structured data collection on the 'wiki', where data were sifted and refined through the challenges, questions and insights offered by CoP members, offered a collaborative way of balancing complexity and coherence. Extraneous details could be omitted, and the method also provided a degree of oversight that helped ensure key points were not overlooked. The process provided a rich data source for analysis, including references to secondary sources (academic articles, reports, websites etc.), and included the forces that were driving SPP (political, environmental and social) and, importantly, insights into how SPP was being implemented 'on the ground'.

\subsection{Case Studies}

Reflecting the growing role of cities in the development of more sustainable food systems, the case studies demonstrated innovative public sector food procurement initiatives in four European cities - Malmö (Sweden), Rome (Italy), Copenhagen (Denmark), and Vienna (Austria); and in one region - East Ayrshire (Scotland). The background for each case study, including the scale and scope of the initiatives, details of targets met, and key impacts and outcomes of SPP implementation, includes a mix of environmental impacts (e.g. reductions in GHG emissions, increased percentages of organic food procured), the role of new City Governments as a catalyst for change, and the application of Social Return on Investment (SROI) (Table 2).

Table 2: The background and basic data on the public sector food procurement initiatives used as case studies.

source: adapted from Barling et al, 2013

In Malmö, Sweden - a city of 300,000 inhabitants - change in public sector food procurement began in 1997 with an increase in purchasing of organic food. Major change took place in 2010, when through a participatory process, a policy for Sustainable Development and Food was approved by the local government council. The policy aims to deliver good food of high quality in all public canteens and has targets for all food served in the city to be certified organic by 2020, with greenhouse gas emissions (GHG) related to food cut by 40 percent by 2020 , compared to 2002 levels. At the end of 2012, 40 percent of the food budget (about nine million Euros) was spent on organic food7.

The city of Rome, Italy feeds 150 thousand school children for 190 days per year, serving almost 150 tons of food per day. Food served in schools has undergone a 'quality revolution' since 1999 when a national law (Finance Law 488), reinforced by the personal interest of a Green Party mayor, created a regulatory context that encouraged many municipalities to introduce organic procurement for school canteens. School meal costs are met by a combination of fees paid by parents and municipal budgets. In the latest tendering process for the period 2013-17, the target for organic food procurement remains at 70 percent. New criteria include an emphasis on local products, sourcing produce from social co-operatives, the reduction of energy consumption, and the re-use of leftovers from school canteens.

Organic food on the public plate has been on the political agenda in Denmark since the 1990s as part of a sustainable food strategy. The city of Copenhagen has an annual food budget of 40 million Euros and 1750

\footnotetext{
7 http://www.malmo.se/English/Sustainable-City-Development/Sustainable-food-in-Malmo.html
} accessed 26 August 2014. 
kitchen employees prepare 60 thousand meals on a daily basis. Since 2009, the Organic Programme has been administered by the Copenhagen House of Food, as an independent, non-commercial foundation. The city aims to achieve 90 percent procurement of organic food by 2015. The programme has been partly supported by government strategy to develop public catering as a market for organic foods.

East Ayrshire, south-west Scotland, is a mix of urban and rural areas. It has a population of 120 thousand with higher than average levels of deprivation. East Ayrshire Council has developed and operated innovative procurement practices, prioritizing unprocessed, local and a proportion of organic ingredients for its school meals service since 2004. Procurement favours limiting the number of suppliers and building economies through scale. A key factor for change in East Ayrshire has been to configure/lot the contracts on a manageable scale that enables small and medium enterprises (SMEs) to bid for contracts. A study based on an average size local primary school (300 children) found that annual savings of 37.7 tonnes $\mathrm{CO}^{2}$ or 10.2 carbon (transport/distribution saving) had been achieved by localizing the supply chain. A further study using the Social Return on Investment method (SROI) calculated $£ 6$ value was returned to the local economy for every $£ 1$ spent on the project.

The City of Vienna supplies food to around 85 thousand people in hospitals, schools, kindergartens and nursing homes for the elderly. The 'ÖkoKauf Wien' ('EcoBuy') programme, with targets for organic food procurement, was launched as part of the Vienna Climate Protection Programme in 1999. For kindergartens and for 90 schools offering after-school care (30 thousand children per day) the percentage of the overall spending on organic food has already reached more than 50 percent and more than 90 percent for dairy products. Overall responsibility is with the Department of Environmental Protection but there is cross-departmental coordination through thematic working groups with members from local authorities, NGOs, municipal administrations and companies, and includes public procurement practitioners from all parts of the administration. The city of Vienna saved €44.4 million and over 100,000 tonnes of $\mathrm{CO} 2$ between 2001 and 2007 through its 'EcoBuy' programme.

\section{Results}

Detailed analysis of the driving forces that led to the implementation of SPP (Table 3) shows how all five case studies implemented SPP as part of wider political strategies, and that effective facilitators at political, administrative, cultural and commercial levels were crucial for building the context. Following the Attitudes-Facilitators-Infrastructure (AFI) framework proposed by Akenji (2014), this included: supportive politicians (national and local), procurement officers and catering staff; a cultural context that supported changing provisioning routines and practices; and innovative criteria for awarding contracts that acknowledged the socio-environmental quality of the products and services offered. Appropriate infrastructure was also crucial for supporting change, such as clear political goals, the allocation of funding to support these processes within an established timeframe, and cross-departmental commitment and cooperation

Analysis also demonstrates a split between cities where transition to more sustainable procurement began with GPP - for example, tie-in with other initiatives to reduce GHG emissions (Malmö), protecting groundwater from pesticide residues (Copenhagen), and Vienna's Climate Protection Programme - and others (Rome and East Ayrshire) that adopted a more holistic approach to sustainability from the outset, with more direct links to social and ethical outcomes. This observation suggests that how legislation is enacted at the national level and interpreted within political strategies at the local level is a key 
driver for SPP. For example, although change in Rome began with national legislation that encouraged organic food procurement, the city adopted an inclusive and incremental approach and used a broader interpretation of what constituted 'quality' meals in its local schools, incorporating healthy food, local community commitment and public health education. Likewise in Copenhagen, where tools and regulations existed to meet minimum standards for GPP at the national level, there was also evidence that voluntary action and collaboration at the municipal level and between sectors resulted in more sustainable procurement practices. These practices made the link between training for procurement officers and canteen staff, menu planning and the procurement of ingredients to support healthy eating and more sustainable diets, with public education that aimed to encourage more widespread take-up beyond the public sector canteen.

Table 3: The driving forces that led to the implementation of SPP in the case studies. source: adapted from Barling et al, 2013

\begin{tabular}{|c|c|c|c|c|}
\hline $\begin{array}{l}\text { Case } \\
\text { study }\end{array}$ & $\begin{array}{c}\text { Dept. } \\
\text { responsible }\end{array}$ & $\begin{array}{c}\text { Political } \\
\text { forces }\end{array}$ & $\begin{array}{l}\text { Environmental } \\
\text { forces }\end{array}$ & $\begin{array}{l}\text { Social } \\
\text { forces }\end{array}$ \\
\hline Malmö & $\begin{array}{l}\text { City of Malmö's } \\
\text { Service Dept. and } \\
\text { Environment Dept. }\end{array}$ & $\begin{array}{l}\text {-political will to } \\
\text { change; } \\
\text { - policy adopted } \\
\text { across all service } \\
\text { depts.; } \\
\text { - funding for training. }\end{array}$ & $\begin{array}{l}\text { - tie-in with other city } \\
\text { initiatives to reduce GHG } \\
\text { emissions. }\end{array}$ & $\begin{array}{l}\text { - involving those who } \\
\text { prepare the food to } \\
\text { ensure support for } \\
\text { changing consumption } \\
\text { routines and practice. }\end{array}$ \\
\hline Copenhagen & $\begin{array}{l}\text { Copenhagen House } \\
\text { of Food, an } \\
\text { independent, non- } \\
\text { commercial } \\
\text { foundation. }\end{array}$ & $\begin{array}{l}\text { - clear political goals } \\
\text { and time frame for } \\
\text { implementation; } \\
\text { - finance allocated to } \\
\text { support the process } \\
\text { of change. }\end{array}$ & $\begin{array}{l}\text { - need to protect ground } \\
\text { water resources from } \\
\text { pesticides; } \\
\text { - targets to reduce } \mathrm{CO}^{2} \\
\text { emissions. }\end{array}$ & $\begin{array}{l}\text { - creating food literacy } \\
\text { among children and } \\
\text { young people; } \\
\text { - advocating more } \\
\text { sustainable } \\
\text { and healthy food } \\
\text { consumption. }\end{array}$ \\
\hline Vienna & $\begin{array}{l}\text { Overall } \\
\text { coordination: Dept. } \\
\text { of Environmental } \\
\text { Protection of the } \\
\text { Municipality. } \\
\text { Programme } \\
\text { coordination: } \\
\text { General Directorates } \\
\text { of the Viennese } \\
\text { Municipality. }\end{array}$ & $\begin{array}{l}\text { - commitment and } \\
\text { cooperation of } \\
\text { government officials } \\
\text { across departments; } \\
\text { - development } \\
\text { funding available; } \\
\text { - international } \\
\text { recognition. }\end{array}$ & $\begin{array}{l}\text { - Vienna's Climate } \\
\text { Protection Programme. }\end{array}$ & $\begin{array}{l}\text { - motivating more } \\
\text { sustainable purchasing } \\
\text { amongst procurement } \\
\text { officers; } \\
\text { - motivating chefs to } \\
\text { cook from scratch. }\end{array}$ \\
\hline Rome & $\begin{array}{l}\text { Municipality of } \\
\text { Rome }\end{array}$ & $\begin{array}{l}\text { - political will to } \\
\text { change; } \\
\text { - inclusive and } \\
\text { incremental } \\
\text { approach. }\end{array}$ & $\begin{array}{l}\text { - national law (1999) } \\
\text { created regulatory } \\
\text { context that encouraged } \\
\text { organic procurement at } \\
\text { municipal level. }\end{array}$ & $\begin{array}{l}\text { - broader } \\
\text { interpretation of } \\
\text { 'quality' meals; } \\
\text { - innovative award } \\
\text { criteria developed } \\
\text { the socio- } \\
\text { environmental quality } \\
\text { of the products and } \\
\text { services offered; } \\
\text { - food education. }\end{array}$ \\
\hline $\begin{array}{l}\text { East } \\
\text { Ayrshire }\end{array}$ & $\begin{array}{l}\text { East Ayrshire } \\
\text { Council }\end{array}$ & $\begin{array}{l}\text {-national policy and } \\
\text { legislative support; } \\
\text { - 'joined-up' policy- } \\
\text { making and local } \\
\text { community strategy. }\end{array}$ & $\begin{array}{l}\text { - strategy to promote } \\
\text { environmental } \\
\text { sustainability through } \\
\text { emphasis on local food } \\
\text { products. }\end{array}$ & $\begin{array}{l}\text { - addressing health } \\
\text { inequalities; } \\
\text { - food education re: } \\
\text { impacts on health and } \\
\text { the environment; } \\
\text { - building local } \\
\text { economies. }\end{array}$ \\
\hline
\end{tabular}




\subsection{Integrating GPP and SPP priorities}

Table 4 details the relationships and synergies between environmental, social/heath and socio-economic criteria that took place 'on the ground'. Environmental criteria, including less meat and organic and seasonal fresh food, were pivotal in all cases. However, these criteria did not stand alone in a 'green' purchasing box but were infused with social factors, such as criteria for sourcing fair trade products, and ingredients with high animal welfare standards and from sustainable fisheries. There were also 'trade-offs' that balanced the environmental, social and economic costs. For example, school canteens in Malmö reduced the amount of meat served and replaced it with more seasonal fruit and vegetables.

Social criteria were split between those directly concerned with diet and health to improve the quality of food served and raise nutritional standards, and others associated with socio-economic factors that affected those working within public sector catering facilities, such as education and training for catering staff and better employment practices; and others related to wider impacts, including education to raise public awareness, impacts on the local and regional economy, and fair trade.

Table 4: Details of the relationships and synergies between environmental, social/heath and socio-economic criteria that led to practical implementation of SPP 'on the ground'. source: adapted from Barling et al, 2013

\begin{tabular}{|c|c|c|c|}
\hline $\begin{array}{l}\text { Case } \\
\text { Study }\end{array}$ & $\begin{array}{l}\text { Environmental } \\
\text { criteria }\end{array}$ & $\begin{array}{l}\text { Social/health } \\
\text { criteria }\end{array}$ & $\begin{array}{l}\text { Socio-economic } \\
\text { criteria }\end{array}$ \\
\hline Malmö & $\begin{array}{l}\text { - certified organic food } \\
\text { and associated } \\
\text { environmental benefits; } \\
\text { - less meat; } \\
\text { - sustainable fishing; } \\
\text {-seasonal food. }\end{array}$ & $\begin{array}{l}\text { - healthy food of high quality in } \\
\text { all public canteens. }\end{array}$ & $\begin{array}{l}\text { - budgets for training catering staff; } \\
\text { - continuous work with and training } \\
\text { for catering staff about why and how } \\
\text { they should change their way of } \\
\text { purchasing and cooking; } \\
\text { - sourcing of fair trade products. }\end{array}$ \\
\hline Copenhagen & $\begin{array}{l}\text { - organic food } \\
\text { procurement targets; } \\
\text { - less meat; } \\
\text { - more fresh, seasonal and } \\
\text { local vegetables and } \\
\text { fruits; } \\
\text { - less food waste. }\end{array}$ & $\begin{array}{l}\text { - healthy food as part of the } \\
\text { urban sustainable development } \\
\text { programme. }\end{array}$ & $\begin{array}{l}\text { - education and training for catering } \\
\text { staff - the principle of the 'Organic } \\
\text { Kitchen'. }\end{array}$ \\
\hline Vienna & $\begin{array}{l}\text { - organic production; } \\
\text { - no genetic modification; } \\
\text { - less meat; } \\
\text { - seasonal and organic } \\
\text { fruit and vegetables; } \\
\text { - fish from sustainable } \\
\text { sources; } \\
\text { - no packaging of meals. }\end{array}$ & $\begin{array}{l}\text {-emphasis on healthy eating; } \\
\text { - 'naturally good plate' that } \\
\text { includes one third regional } \\
\text { ingredients and high animal } \\
\text { welfare standards; } \\
\text { - reduction of trans-fatty acids. }\end{array}$ & $\begin{array}{l}\text { - emphasis on regional impacts; } \\
\text { - sourcing of fair trade products. }\end{array}$ \\
\hline Rome & $\begin{array}{l}\text { - mandatory list of organic } \\
\text { products; }\end{array}$ & $\begin{array}{l}\text { - PDO/PGI products; } \\
\text { - varied and nutritious menus }\end{array}$ & $\begin{array}{l}\text { - criteria and budgets to improve } \\
\text { kitchens and eating environments; }\end{array}$ \\
\hline
\end{tabular}




\begin{tabular}{|c|c|c|c|}
\hline & $\begin{array}{l}\text { - seasonality and } \\
\text { territoriality; } \\
\text { - lower food miles; } \\
\text { - less food waste; } \\
\text { - recycling. }\end{array}$ & & $\begin{array}{l}\text { - education projects involving } \\
\text { teachers and parents; } \\
\text { - training for staff; } \\
\text { - sourcing fair trade bananas and } \\
\text { chocolate bars. }\end{array}$ \\
\hline $\begin{array}{l}\text { East } \\
\text { Ayrshire }\end{array}$ & $\begin{array}{l}\text { - seasonality, freshness } \\
\text { and localness; } \\
\text { - responsible use of } \\
\text { resources; } \\
\text { - lower food miles. }\end{array}$ & $\begin{array}{l}\text { - better quality meals; } \\
\text { - public health and nutrition. }\end{array}$ & $\begin{array}{l}\text { - investment in the local economy; } \\
\text { - better employment practices; } \\
\text { - improved links with education and } \\
\text { community learning. }\end{array}$ \\
\hline
\end{tabular}

\subsection{Challenges}

The findings underline the importance of maintaining political continuity in order to reach SPP policy goals. One key challenge was the interpretation of EU regulations on procurement contracts. Practical implementation meant preparing tenders to meet EU requirements whilst adapting strategies to local and cultural contexts and calibrating demand and supply of food ingredients. Valuing social (social/health and socioeconomic) considerations when evaluating tenders was not made easy because of strict rules on awarding contracts on 'best value' and 'the economically most advantageous tender' (i.e. low cost). In order to overcome these market-led constraints, there was evidence of an incremental approach to change that shifted food procurement and menu planning towards healthy outcomes in all the case studies, with innovative practices that did not breach EU regulations. Examples included: dividing tenders for major ingredients into smaller product 'lots ' to enable smaller producers and suppliers to bid for contracts (e.g. East Ayrshire); and the incorporation of specific characteristics required in foods, such as certified organic (e.g. Malmö).

In addition, the findings also reveal how budgetary constraints were a challenge, especially when the cost of ingredients increased. Implementing and maintaining innovative and more sustainable procurement practices stretched from production to consumption, including: maintaining sufficient supplies; ensuring that SMEs maintained competitiveness, could manage distribution, and tender for contracts; ensuring that catering companies remained financially viable in the period of adjustment; and encouraging 'spill over' into private consumption practices. SPP was also bound up with technological capabilities, including countering the use of cook and chill systems, and with building on-site kitchens and changing fundamental principles and routines in catering facilities. 


\section{Discussion}

The findings reflect the reality of devising and implementing innovative approaches to more sustainable public sector food procurement in Europe, the effects of cultural and political framings within national contexts, and the difficulties of practical implementation. The CoP provided the means for members to exchange and revalue their knowledge about public sector food procurement. The joint collaboration in researching and constructing the case studies provided a strong sense of ownership and was a helpful device for demonstrating the reality of SPP implementation 'on the ground'.

Recent policy reforms to support the renewed focus on green growth strategies and the emerging discourse on nutrition and sustainability raise questions about 'measuring' progress within wider systems of implementation; the next two sub-sections explore this within the context of life cycle assessment methodologies, EU legislative reform, and sustainable diets.

\subsection{Beyond 'green'}

The case studies demonstrate how public procurement can lead to quantifiable outcomes (e.g. through lower GHG emissions) and there is evidence that initial financial outlay had been countered by savings made in other areas, supporting Rimmington et al's (2006) argument that 'what gets measured gets managed.' However, systems and indicators require further development if they are to incorporate full life cycle costs that are tailored to local contexts and that are not too complex to manage within urban governments, if progress is to extend procurement beyond green purchasing and create more sustainable food systems and better public health nutrition. As has already been recognised, methods and techniques to measure environmental impacts of products using LCA are more advanced and the evidence base is stronger, whereas system boundaries for 'measuring' the environmental footprint of organisations as procurer are only in the early stages of development (Pelletier et al, 2014), as are methodologies that integrate social impacts into LCA methodologies (Smith and Barling, 2014).

Equally, although the dynamic between policy and practice is constantly evolving as urban governments assume more authority and responsibility for sustainable development, the findings show that transition to more sustainable procurement is very dependent on political will and leadership and an infrastructure that is able to balance the complexity of the inter-relationships between economic, environmental and social 
drivers to effect change. The reforms to EU directives on procurement (2014) - that aim to address the perceived lack of clarity between social and environmental criteria - must be implemented at the national level by April 2016. These new rules and procedures, including the right to value social goals when evaluating tenders and the use of full life cycle costing, pick-up on innovations implemented by urban governments in the case studies. However, given the overall market-led EU policy framework, a lack of political ambition to move beyond GPP appears likely to remain in the foreseeable future.

\subsection{Impacts on nutrition and public health}

All the case studies demonstrated an increase in the procurement of better quality food, including organic, seasonal and local fresh food. This is in-line with current discourse on sustainable diets to promote foods with less environmental impacts and eating perishable produce in season. However, there were anomalies, such as when the 'trigger' for change came from environmental initiatives (Malmö, Copenhagen and Vienna). In these instances, meeting organic 'targets' often meant sourcing imported food through central suppliers that resulted in 'trade-offs' between environmental, social and economic costs. As Akenji (2013) puts it, these differences between GPP and SPP might seem semantic, but for policy makers and practitioners these 'trade-offs' have serious implications for interpreting more sustainable food procurement and for implementing processes and practices associated with sustainable diets.

\section{Conclusions}

The findings underline the need to explore how consistent definitions for green and sustainable public sector food procurement can be refined and standardized in order to support governments at all levels in reviewing and analysing their current food procurement strategies and practices to improve sustainability. Clarifying the difference between GPP and SPP, with political continuity that supports and enables policymakers and practitioners to take an incremental approach to change, would make an important contribution to delivering more sustainable food systems and better public health nutrition.

The research shows that there is a scarcity of data and indicators for SPP and there is a need for further research studies to gather empirical data in order to compile an evidence base on the scope and scale of food procurement schemes. This includes the mechanisms employed (what works), the tangible benefits for sustainability and how these are extended and mobilized in the wider society. 
More broadly, the future trajectories of green growth strategies and sustainable diets need to converge in order to further understanding of how human health is interwoven with the health of eco-systems and deliver sustainability goals.

\section{Acknowledgements:}

The authors gratefully acknowledge funding from the European Community under the Seventh Framework Programme theme "Environment" for the collaborative project ENV.2010.4.2.3-3 FOODLINKS. Thanks and acknowledgments are also due to Bettina Bock, Annemiek Canjels, Francesca Galli, Femke Hoekstra, Francesco de Iacovo and Anita Selunda and to everyone else who contributed to the joint collaboration on the case study report. The views expressed are the sole responsibility of the authors.

\section{References}

Ahi, P. and Searcy, C. (2013) A comparative literature analysis of definitions for green and sustainable supply chain management. Journal of Cleaner Production, 52, pp. 329341

Akenji, L. (2013) Consumer scapegoatism and limits to green consumerism. Journal of Cleaner Production, 63, pp.13-23.

Barling, D. et al. (2013) 'Revaluing Public Sector Food Procurement in Europe: An Action Plan for Sustainability', available at:

http://www.foodlinkscommunity.net/fileadmin/documents organicresearch/foodlinks Lpublications/Foodlinks report low.pdf accessed 3 March 2015

Benson, E. (2014) ‘Real Green Economies’. Conference Report (WP1272), Wilton Park. 24-26 February 2014.

Brammer, S. and Walker, H. (2011) Sustainable procurement in the public sector: an international comparative study. International Journal of Operations \& Production Management, 31(4), pp. 452-476.

Bratt, C. et al (2013) Assessment of criteria development for public procurement from a strategic sustainability perspective. Journal of Cleaner Production, 52, pp. 309-316.

De Schutter, O. (2014) 'The Power of Procurement: public purchasing in the service of realizing the right to food.' Briefing note 08, April 2014.

Evans, L. et al. (2010) 'National Green and Sustainable Public Procurement Criteria and Underlying Schemes, Report written by AEA Technology for DG Environment, European Commission, Didcot.

Garnett, T. (2014) 'What is a sustainable healthy diet? A discussion paper.' Food Climate Research Network, April 2014.

GGBP (2013) 'Green Growth in Practice: Lessons from Country Experiences', Green Growth Best Practice ( http://www.ggbp.org/ accessed 24 November 2014). 
Johnston, J.L. et al. (2014) Understanding Sustainable Diets: a descriptive analysis of the determinants and processes that influence diets and their impact on health, food security, and environmental sustainability. Advances in Nutrition 5, pp. 418-429

Lang, T. (2014) Sustainable Diets: Hairshirts or a better food future? Development, 57 (2), pp. 240-256.

Lang, T. and Barling, D. (2013) Nutrition and Sustainability: an emerging food policy discourse. Proceedings of the Nutrition Society, 72 (1), pp.1-12.

Lave, J. and Wenger, E. (1991) Situated learning: legitimate peripheral participation, Cambridge, Cambridge University Press

Macdiarmid, J.I. (2013) Is a healthy diet an environmentally sustainable diet? Proceedings of the Nutrition Society 72, pp. 13-20 doi:10.1017/S0029665112002893

Nogueiro, L. and Ramos, T.B. (2014) The integration of environmental practices and tools in the Portuguese local public administration. Journal of Cleaner Production, 76, pp. 20-31.

Morgan, K. J. (2015) Nourishing the city: The rise of the urban food question in the Global North. Urban Studies, 52(8) pp. 1379-1394

Morgan, K. J. and Sonnino, R. (2008) The school food revolution: public food and the challenge of sustainable development. Oxford: Earthscan.

OECD (2014) Green Growth Indicators for Agriculture: A Preliminary Assessment, OECD Green Growth Studies, OECD Publishing. DOI: 10.1787/9789264223202-en accessed 1 December 2015

OECD (2012) "Progress made in implementing the OECD Recommendation on Enhancing Integrity in Public Procurement: Report to Council", www.oecd.org/corruption/fightingcorruptioninthepublicsector/ accessed 1 December 2015

Pelletier et al (2014) The European Commission Organisation Environmental Footprint method: comparison with other methods, and rationales for key requirements. Int J Life Cycle Assess 19:387-404.

Perera, O. (2012) 'The Case for Pursuing Sustainable Public Procurement in Lower Income Countries', International Institute for Sustainable Development: Manitoba.

Preuss, L. (2011) On the contribution of public procurement to entrepreneurship and small business policy. Entrepreneurship \& Regional Development: An International Journal, 23 (9-10) pp. 787-814.

Preuss, L. (2007) Buying into our future: the range of sustainability initiatives in local government procurement. Business Strategy and the Environment, 16 (5) pp. 354-365.

Puppim de Oliveira, J.A. et al. (2013) Green economy and governance in cities: assessing good governance in key urban economic processes. Journal of Cleaner Production, 58, pp. 138-152. 
Rimmington, M. et al (2006) Corporate social responsibility and sustainable food procurement. British Food Journal, 108 (10), pp. 824-837.

Smith, J. and Barling, D. (2014) Social impacts and life cycle assessment: proposals for methodological development for SMEs in the European food and drink sector. International Journal of Life Cycle Assessment, 19(4), pp. 944-949

Smith, J. and Barling, D. (2013) 'Foodlinks: Re-valuing Public Sector Food Procurement.' Final Report to the European Commission Deliverable 4.1

http://www.foodlinkscommunity.net/fileadmin/documents organicresearch/foodlinks Lpublications/smith-barling-d-4-1.pdf accessed 18 June 2015.

Sonnino, R. (2009) Quality food, public procurement, and sustainable development: the school meal revolution in Rome. Environment and Planning A, 41(2), pp. 425-440.

Testa, F. et al (2014) Drawbacks and opportunities of green public procurement: an effective tool for sustainable production. Journal of Cleaner Production doi:10.1016/j.jclepro.2014.09.092

UNEP (2012) Green Economy Briefing Paper: Metrics and Indicators (http://www.unep.org/greeneconomy/Portals/88/GE INDICATORS\%20final.pdf accessed 24 November 2014)

Wenger, E., McDermott, R. and Snyder, W. M. (2002) Cultivating Communities of Practice, Boston, MASS, Harvard Business School Press. 